\title{
EVOLUÇÃO E SUPREMACIA MASCULINA: POR QUE AS MULHERES ACEITARAM?
}

Regina Célia Souza Brito'

A história evolutiva da humanização tem inicio com a mudança em direção ao andar ereto. 0 ambiente transformado, ao selecionar a bipedia, selecionou também transformações anatômicas e fisiológicas importantes na pelve da fêmea bipede. Após alguns milhões de anos, esta fêmea enfrentou uma nova mudança importante: o cérebro do seu filhote, agora do novo gênero Homo, começou a expandir-se, conflitando com sua pelve transformada.

A seleção natural privilegiou os bebês que nasciam progressivamente imaturos, sendo que o desenvolvimento posterior ao nascimento veio solucionar o impasse. A fragilidade e dependência do filhote exigiram novas adaptações. Aquela era a época adequada para a seleção natural transformar parceiros sexuais em pais. A adaptação mais importante, nesta direção, foi a perda do cio, com a ovulação silenciosa, caracteristica da fêmea hominidea; o macho não tinha indícios de quando copular para garantir a paternidade dos filhotes. A solução era a permanência junto a ela, que gradativamente se tornava mais e mais disponivel para o sexo. A disponibilidade sexual da fêmea ocorria, inclusive, quando esta estava fecundada. 
A seleção da estrutura clitoriana feminina, responsável por esta disponibilidade, não tem nenhuma relação com a fecundação em si. A resposta orgástica prazerosa é possível porque o clitóris é ricamente enervado e irrigado, e o funcionamento desta estrutura demanda a ativação de vários circuitos cerebrais dos sistemas primários de recompensa. Uma ativação de tal monta, em um órgão extremamente oneroso, como o cérebro humano, demonstra a inequívoca importância desta estrutura para a sobrevivência da espécie.

0 padrão sexual exibido pela fêmea humana foi um dos responsáveis pela permanência de seu parceiro junto a ela e, assim, as mudanças nela selecionadas, por sua vez, selecionavam os repertórios paternais no macho, garantindo a sobrevivência da espécie e transmitindo esta característica aos descendentes. Estes eventos, que caracterizaram a formação de elos mais estreitos entre o casal humano, foram sendo incorporados pela cultura como prova do papel apenas reprodutivo da mulher, fortalecendo historicamente a crença na submissão e inferioridade feminina.

Com o advento da revolução contraceptiva, a opção feminina pela maternidade pôde ser exercida de maneira segura. 0 direito de escolher ter filhos e quando, tem mudado gradativamente seu papel social e permitido o exercício da sexualidade voltada para o prazer e a afetividade, função principal para a qual seu órgão sexual, o clitóris, foi selecionado.

Embora grande parte das mulheres ainda esteja excluida do acesso ao direito de controlar sua reprodução, assim como de outros direitos, as que têm conseguido este acesso demonstram que são cidadãs de primeira classe. Mulheres e homens sofreram pressões evolutivas diferentes, que os modelaram com caracteristicas próprias, características estas que se complementavam em uma divisão de trabalho geradora de tal sucesso reprodutivo, que hoje é uma das variáveis que coloca em risco a nossa sobrevivência. 